ORIGINAL PROF-2186

\title{
HELICOBACTER PYLORI INFECTION
}

\section{C-REACTIVE PROTEIN IN PATIENTS}

\author{
Dr. Muhammed Khalid Shaikh, Dr. Javed Akhtar Samo, Dr. Samina Shaikh, Dr. Syed Zulfiquar Ali Shah
}

ABSTRACT... Objective: To determine the frequency of raised C-reactive protein in patients with Helicobacter pylori infection. Design: Cross sectional descriptive study. Setting: Department of Medicine at Liaquat University Hospital (tertiary care teaching hospitals). Period: April 2012 to September 2012. Patients and methods: All patients above 12 years of age, of either gender with history of nausea, vomiting, recurrent abdominal pain, dyspepsia or abdominal discomfort, heartburn, bloating and halitosis through casualty outdoor department (COD) or admitted in medical unit were evaluated and enrolled in the study. For the detection of Helicobacter pylori the $3 \mathrm{cc}$ venous blood sample of relevant patients was taken in a disposable syringe. After detecting the $\mathrm{H}$. pylori infection, the $\mathrm{H}$. pylori individuals were further evaluated for serum C-reactive protein by taking $3 \mathrm{cc}$ venous blood sample in a disposable syringe and sent to laboratory for analysis. The patients with raised CRP were also evaluated for their lipid profile to detect dyslipidemia. The data was collected on predesigned proforma and then entered, saved and analyzed in SPSS version 10.00. Results: During six month study period total 92 patients with Helicobacter pylori infection were recruited and studied for serum C-reactive protein. The mean age \pm SD for overall population was $43.22 \pm 8.31$, whereas the mean age $\pm S D$ for male and female population was $41.24 \pm 7.94$ and $44.76 \pm 9.42$ respectively. The raised CRP was detected in $61(66 \%)$ patients $(p=0.02)$. The mean value \pm SD of raised CRP in male and female population was $6.30 \pm 2.86$ and $7.82 \pm 3.21$ respectively. 0 f $61(66 \%)$ patients with raised CRP the dyslipidemia was identified in $45(74 \%)$ patients $(p=0.03)$. Out of 45 , the raised triglycerides was observed in $08(18 \%)$ patients, low HDL in $10(22 \%)$ patients, raised LDL in $13(29 \%)$, raised cholesterol in 07(16\%) whereas 07(16\%) patients had mix dyslipidemia. Conclusions: The raised CRP was identified in patients with Helicobacter pylori infection, the dyslipidemia was observed in raised CRP population.

Key words: C-reactive protein, CRP, Helicobacter pylro, H. pylori, Dyslipidemia, Lipid profile.

Article Citation

Shaikh MK, Samo JA, Shaikh S, Shah SZA. C-reactive protein in patients with helicobacter pylori infection. Professional Med J 2013;20(5): 667-671.

\section{INTRODUCTION}

Peptic ulcer is a leading cause of morbidity and mortality and Helicobacter pylori ( $\mathrm{H}$ pylori) infection is recognized as the most important causes of peptic ulcer disease ${ }^{1}$. It is a type of bacteria responsible for widespread infection with more than $50 \%$ of the world's population infected, even though $80 \%$ of those infected have no symptoms ${ }^{2}$. Infection with $\mathrm{H}$. pylori has been recognized as a public health problem worldwide and more prevalent in developing than the developed countries ${ }^{3}$. The prevalence appears to be higher in African-American and Hispanic populations, although this is likely related to socioeconomic rather than racial factors ${ }^{4}$. The lower rate of infection in the West is largely attributed to higher hygiene standards and widespread use of antibiotics.

C-reactive protein (CRP) is an acute phase protein synthesized by hepatocytes. In response to infection or tissue inflammation, CRP production is rapidly stimulated by cytokines, particularly interleukin IL-6, $\mathrm{IL}-1$ and tumour necrosis factor ${ }^{5,6}$. Although its exact function in vivo is not known, it probably has a role in opsonization of infectious agents and damaged cells ${ }^{7}$. Two different uses of CRP have been investigated. Firstly, as a diagnostic tool and secondly, as a prognostic and follow-up test, as serial measurements may be useful to evaluate the response to antibiotic treatment and to detect complications in patients with infections.

There is strong evidence that CRP is a powerful predictor of incident cardiovascular events independent of levels of LDL cholesterol ${ }^{8}$. The CRP level in individuals free from acute illness is reproducible and its determinants reportedly include age and smoking $^{9}$ while substantial heritability (35-40\%) was also reported in familial aggregation studies $^{10}$. The present study was conducted at teriarity care teaching hospital of Hyderabad by evaluating the 
association between $\mathrm{H}$. pylori infection and serum CRP levels which seemed important to elucidate the relevance of $\mathrm{H}$. pylori infection with coronary heart disease, especially atherosclerosis.

\section{PATIENTS AND METHODS}

This cross sectional descriptive study was conducted in the department of Medicine at Liaquat University Hospital (tertiary care teaching hospitals) from April 2012 to September 2012. All patients above 12 years of age, of either gender with history of nausea, vomiting, recurrent abdominal pain, dyspepsia or abdominal discomfort, heartburn, bloating and halitosis through casualty outdoor department (COD) or admitted in medical unit were evaluated and enrolled in the study. The detailed history of all such patients was taken and complete physical and relevant clinical examination was performed. For the detection of Helicobacter pylori the $3 \mathrm{cc}$ venous blood sample of relevant patients was taken in a disposable syringe, the sera were separated from blood samples immediately after blood draw. They were kept in a deep freezer at $80^{\circ} \mathrm{C}$ until analyzed. A commercially available direct ELISA kit was used to determine the presence of $\mathrm{H}$. pylori infection. The seropositive was defined as $\mathrm{H}$. pylori IgG antibody more than $10 \mathrm{U} / \mathrm{ml}$. After detecting the $\mathrm{H}$. pylori infection, the $\mathrm{H}$. pylori individuals were further evaluated for serum C-reactive protein by taking 3cc venous blood sample in a disposable syringe and sent to laboratory for analysis. The normal reference range for $C$-reactive protein is $0-1.0 \mathrm{mg} / \mathrm{dL}$ while the level $>1.0 \mathrm{mg} / \mathrm{dL}$ was considered as raised. The patients with raised CRP were also evaluated for dyslipidemia. The exclusion criteria of the study were the patients already on Helicobacter pylori eradication and lipid lowering therapy, known (diagnosed) cases of chronic liver disease (CLD) and cirrhosis, hypothyroidism, recent myocardial infarction, recent stroke, chronic renal failure (CRF), diabetes mellitus (DM), familial hypercholesterolemia and hypertriglyceridemia, pregnant ladies, rheumatic fever, various infectious diseases (meningitis, poliomyelitis, infectious mononucleosis, syphilis), malignancy, rheumatoid and septic arthritis. The informed consent was taken from every patient or from attendants of patients after full explanation of procedure regarding the study, and all such maneuvers was performed under medical ethics and through the cooperation of whole research team. The data was collected on predesigned proforma and then entered, saved and analyzed in SPSS version 10.00. The frequency and percentage (\%) was calculated for raised serum CRP level in patients with Helicobacter pylori infection and gender distribution. The mean and standard deviation (SD) was calculated for age and CRP. The stratification was done for age, gender, Creactive protein (CRP) in patients with Helicobacter pylori infection.. The independent - samples t-test was applied between categorical variables while the chisquare test was applied at 95\% confidence interval (CI) to determine the statistical difference in gender and the $p$-value $\leq 0.05$ was considered as statistically significant.

\section{RESULTS}

During six month study period total ninety two patients with Helicobacter pylori infection were recruited and studied for their serum $\mathrm{C}$-reactive protein status. The mean age $\pm S D$ for overall population was $43.22 \pm 8.31$, whereas the mean age $\pm S D$ for male and female population was $41.24 \pm 7.94$ and $44.76 \pm 9.42$ respectively. The raised CRP was detected in 61(66\%) patients shown in Table-l. The mean \pm SD of CRP in overall population was $6.73 \pm$ 2.52 where as the mean \pm SD of CRP in male and female population was $3.77 \pm 1.93$ and $4.62 \pm 2.95$ respectively. The mean age \pm SD of male and female subjects with raised CRP was $42.94 \pm 11.53$ and $46.55 \pm 9.64$ respectively. The mean age \pm SD of raised CRP in male and female population was $6.30 \pm 2.86$ and $7.82 \pm 3.21$ respectively. Of $61(66 \%)$ patients with raised CRP the dyslipidemia was identified in 45(74\%) patients shown in Table-II. 


\begin{tabular}{|c|c|c|c|c|}
\hline \multirow[t]{2}{*}{ Gender } & \multicolumn{3}{|c|}{ CRP } & \multirow[t]{2}{*}{ P-value } \\
\hline & Raised & Normal & Total & \\
\hline Male & $\begin{array}{c}40 \\
(65.6 \%)\end{array}$ & $\begin{array}{c}27 \\
(87.1 \%)\end{array}$ & $\begin{array}{c}67 \\
(72.8 \%)\end{array}$ & \multirow{3}{*}{$0.02^{\star}$} \\
\hline Female & $\begin{array}{c}21 \\
(34.4 \%)\end{array}$ & $\begin{array}{c}04 \\
(12.9 \%)\end{array}$ & $\begin{array}{c}25 \\
(27.2 \%)\end{array}$ & \\
\hline Total & $\begin{array}{c}61 \\
(100 \%)\end{array}$ & $\begin{array}{c}31 \\
(100 \%)\end{array}$ & $\begin{array}{c}92 \\
(100 \%)\end{array}$ & \\
\hline
\end{tabular}

Table-I. Raised c-reactive protein in relation to gender distribution

$\star{ }^{*}$-value is statistically significant

Pearson Chi-square value $=4.81$; $d f=1$

\begin{tabular}{|l|c|c|c|c|}
\hline \multirow{2}{*}{ Gender } & \multicolumn{3}{|c|}{ Dyslipidemia } & \multirow{2}{*}{ P-value } \\
\cline { 2 - 4 } & Yes & No & Total & \\
\hline Male & $\begin{array}{c}33 \\
(73.3 \%)\end{array}$ & $\begin{array}{c}07 \\
(43.8 \%)\end{array}$ & $\begin{array}{c}40 \\
(65.6 \%)\end{array}$ & \\
\hline Female & $\begin{array}{c}12 \\
(26.7 \%)\end{array}$ & $\begin{array}{c}09 \\
(56.3 \%)\end{array}$ & $\begin{array}{c}21 \\
(34.4 \%)\end{array}$ & \multirow{2}{*}{$0.03^{*}$} \\
\hline Total & $\begin{array}{c}45 \\
(100 \%)\end{array}$ & $\begin{array}{c}16 \\
(100 \%)\end{array}$ & $\begin{array}{c}61 \\
(100 \%)\end{array}$ & \\
\end{tabular}

Table-II. The dyslipidemia in relation to gender distribution

${ }^{\star} P$-value is statistically significant

Pearson Chi-square value $=4.57 ; d f=1$

Out of 45 , the raised triglycerides was observed in 08(18\%) patients, low HDL in 10(22\%) patients, raised LDL in $13(29 \%)$, raised cholesterol in $07(16 \%)$ whereas $07(16 \%)$ patients had mix dyslipidemia. The symptoms observed were nausea $77(84 \%)$, vomiting 82(89\%), recurrent abdominal pain 87(95), dyspepsia or abdominal discomfort $80(87 \%)$, heartburn $75(82 \%)$, bloating and halitosis $79(86 \%)$ and more than one symptom in $85(92 \%)$ patients. Majority of patients 68(74\%) from rural areas while 24(26\%) from urban area of the province.

\section{DISCUSSION}

Some investigations, but not all, found that a chronic infection with Helicobacter pylori $(\mathrm{Hp})$ is associated with deficiencies in $B$ vitamins, elevated plasma total homocysteine concentrations (tHcy) and increased plasma levels of proinflammatory acute-phase proteins. It has been suggested that these factors promote atherogenesis and therefore could mechanistically explain why people infected with Hp might have an increased risk for cardiovascular diseases (CVD) ${ }^{11}$. The present study examined the association of $\mathrm{H}$. pylori seropositivity with CRP irrespective of the gender, age, body mass index (BMI), smoking and alcohol and identified raised CRP in 61 (66\%) individuals, of which 40 were males and 21 were females $(p=0.02)$. CRP is a marker of inflammation and infection of the gastric mucosa with Helicobacter pylori causes an inflammatory reaction. It has been reported that $\operatorname{CagA}(+) H$. pylori strains induce more severe gastric inflammation and are also associated with higher risks of peptic ulcer and gastric cancer $^{12}$. In present study the dyslipidemia was observed in $45(74 \%)$ subjects with raised CRP, the findings are consistent with the study by Kanbay M, et $\mathrm{al}^{13}$. H. pylori infection is associated with coronary artery disease, the pathway to elevate the disease risk is not clear. There are several possibilities for the mechanism underlying a causal role of $\mathrm{H}$. pylori infection in endothelial dysfunction. First, H. pylori may have the direct effect on the structure and function of vascular endothelial cells. Extract of $\mathrm{H}$. pylori has been reported to induce a disturbance of proliferation and apoptosis and to decrease viability of cultured vascular endothelial cells ${ }^{14}$. The second possibility is the nutritional effect of $\mathrm{H}$. pylori ${ }^{15}$. An infection from $\mathrm{H}$. pylori may cause malabsorption of folate, vitamin B6, and vitamin B12. This nutritional defect could lead to failure of methylation by 5-methyl-tetrahydrofolic acid and subsequent hyperhomocysteinanemia, which is toxic to endothelial cells. In past study, serum folate was examined as a molecule connecting $\mathrm{H}$. pylori infection with systemic diseases, resulting in no 
association between the seropositivity and serum folate $^{16}$. CRP is also one of the candidate molecules, but there were limited reports on the association with $\mathrm{H}$. pylori infection. A study on the effects of $\mathrm{H}$. pylori eradication among 78 patients in Turkey reported that serum CRP was significantly reduced among 57 participants with successful eradication, but not among 21 participants in whom the eradication failed $^{17}$. Another study reported that increasing age, $\mathrm{H}$. pylori and Chlamydia pneumoniae infections all associated with raised concentrations of $\mathrm{CRP}^{18}$. The present study demonstrated that $\mathrm{H}$. pylori infection elevates the serum CRP, thereby may increase systemic disease risk.

The present study showed a significant association between $\mathrm{H}$. pylori infection and serum CRP levels, supporting that $\mathrm{H}$. pylori infection may increase the serum CRP. The possible attribution of $\mathrm{H}$. pylori infection to CRP elevation increases the risk of coronary heart disease on the basis of atherosclerosis.

\section{CONCLUSIONS}

The patients with Helicobacter pylori infection had raised CRP level which may be involved in the development of the atherosclerosis via endothelial dysfunction and systemic and vascular inflammation. We also conclude that $\mathrm{H}$. pylori infection may affect lipid metabolism in a way that could increase the risk of atherosclerosis. Thus $H$. pylori infection is an independent risk factor for coronary artery disease. In future large, advance and extensive multidisciplinary studies are mandatory to confirm the association.

\section{Copyright@ 24 June, 2013.}

\section{REFERENCES}

1. Yakoob J, Jafri W, Jafri N, Islam M, Abid S, Hamid S, et al. Prevalence of non-Helicobacter pylori duodenal ulcer in Karachi, Pakistan. World J Gastroenterol. 2005;11(23):3562-5.

2. Devrajani BR, Zaman SM, Shah SZA, Devrajani T,
Lohana RK, Das T. Helicobacter pylori: A Cause of Vitamin B12 Deficiency (A Hospital Based Multidisciplinary Study). World Applied Sciences Journal 2011;12(9): 1378-81.

3. Devrajani BR, Shah SA, Soomro AA, Devrajani T. Type 2 diabetes mellitus: A risk factor for Helicobacter pylori infection: A hospital based case-control study. Int J Diab Dev Ctries.2010;30:22-6.

4. Everhart JE, Moran K, Perez P, Tralka TS, McQuillan G. Seroprevalence and ethnic differences in Helicobacter pylori infection among adults in the United States. J Infect Dis 2000;181(4):1359-63.

5. Dehghan A, Kardys I, de Maat MP, Uitterlinden AG, Sijbrands EJ, Bootsma AH, A et al. Genetic variation, C-reactive protein levels, and incidence of diabetes. Diabetes.2007;56(3):872-8.

6. Ridker PM, Danielson E, Fonseca FA, Genest J, Gotto AM Jr, Kastelein JJ, et al. Rosuvastatin to prevent vascular events in men and women with elevated Creactive protein. $\mathrm{N}$ Engl J Med. 2008;359(21): 2195-207.

7. Shaikh MK, Makhija P, Baloch ZAQ, Mughal MF, Devrajani BR, Shaikh S, et al. C-Reactive Protein in Patients with Ischemic Stroke. World Applied Sciences Journal 2011;15 (9):1220-24.

8. Ridker PM, Rifai N, Rose L. Buring JE, Cook NR. Comparison of C-reactive protein and low-density lipoprotein cholesterol levels in the prediction of first cardiovascular events. N Engl J Med. 2002;347:155765.

9. Brian FM. Evidence of smoke and atherosclerotic fire. CCJM. 2001;68:538-40.

10. Mendall MA, Goggin PM, Molineaux N, Levy J, Toosy T, Strachan D, et al. Relation of Helicobacter pylori infection and coronary heart disease. Br Heart J.1994;71:437-39.

11. Stettin D, Waldmann A, Ströhle A, Hahn A. Association between Helicobacter pylori-infection, C-reactive protein and status of B vitamins. Adv Med Sci.2008;53(2):205-13. 
12. Jafarzadeh A, Hassanshahi GH, Nemati M. Serum levels of high-sensitivity C-reactive protein (hsCRP)in Helicobacter pylori-infected peptic ulcer patients and its association with bacterial CagA virulence factor. Dig Dis Sci.2009;54(12):2612-6.

13. Kanbay M, Gür G, Yücel M, Yilmaz U, Boyacio lu S. Does eradication of Helicobacter pylori infection help normalize serum lipid and CRP levels?. Dig Dis Sci. 2005;50(7):1228-31.

14. Kalia N, Jones C, Bardhan KD. Reed MW, Atherton JC, Brown NJ. Effects of genotypically different strains of Helicobacter pylori on human microvascular endothelial cells in vitro. Dig Dis Sci.2001;46:54-61.

15. Sung JJY, Sanderson JE. Hyperhomocysteinanemia, Helicobacter pylori, and coronary heart disease.
Heart.1996;76:305-7.

16. Tamura A, Fujioka T, Nasu M. Relation of Helicobacter pylori infection to plasma vitamin B12, folic acid, and homocysteine levels in patients who underwent diagnostic coronary arteriography. Am J Gastroenterol. 2002;97(4):861-6.

17. Saribas S, Kocazeybek B, Aslan M, Altun S, Seyhun Y, Oner YA, et al. Do procalcitonin and $C$-reactive protein levels have a place in the diagnosis and follow-up of Helicobacter pylori infections?. J Med Microbiol. 2004;53(Pt7):639-44.

18. Mendall MA, Praful P, Lydia B, Strachan D, Northfield TC. C-reactive protein and its relation to cardiovascular risk factors: a population based cross sectional study. BMJ. 1996;312:1061-65.

\section{AUTHOR(S):}

1. DR. MUHAMMED KHALID SHAIKH

Assistant professor

Department of Medicine

Liaquat University of Medical and Health Sciences,

Jamshoro / Hyderabad (LUMHS)

2. DR. JAVED AKHTAR SAMO

Ghulam Muhammad Mahar Medical College (GMMMC) Sukkur, Sindh, Pakistan

3. DR. SAMINA SHAIKH

Department of Medicine

Liaquat University of Medical \& Health Sciences (LUMHS),

Jamshoro-Pakistan
4. Dr. Syed Zulfiquar Ali Shah

Department of Medicine

Liaquat University of Medical \& Health Sciences, Jamshoro-Pakistan

Correspondence Address:

Dr. Syed Zulfiquar Ali Shah

House No. 279, Doctors, Colony Hirabad

Hyderabad, Sindh, Pakistan

zulfikar229@hotmail.com

Article received on: 11/01/2013 Accepted for Publication: $24 / 06 / 2013$ Received after proof reading: 19/09/2013

\section{PREVIOUS RELATED STUDIES}

Farid Imanzadeh, Amir Imanzadeh, Ali Akbar Sayyari, Mehrnosh Yeganeh, Hazhir Javaherizadeh, Bizhan Hatamian. HELICOBACTER PYLORI INFECTION; IN CASES WITH AND WITHOUT SUBJECTIVE HALITOSIS (Original) Prof Med Jour 17(4) 543545 Oct, Nov, Dec 2010.

Qurban Ali Khaskheli, Saleem A Kharal, Anjum Syed, Qazi Muhammad Rizwan, Muhammad Asif Durrani. SERODIAGNOSIS OF HELICOBACTER PYLORI INFECTION (Original) Prof Med Jour 9(2) 145-153 Apr, May, Jun, 2002. 